\title{
Pengembangan Aplikasi Mobile Crowdsourcing Informasi Layanan Umum (Studi Kasus di Kabupaten Buleleng)
}

\author{
I Made Hari Antara ${ }^{1}$, I Gede Mahendra Darmawiguna ${ }^{2}$, I Made Ardwi Pradnyana ${ }^{3}$ \\ Program Studi Pendidikan Teknik Informatika \\ Jurusan Teknik Informatika \\ Fakultas Teknik dan Kejuruan \\ Universitas Pendidikan Ganesha \\ Email : made.hari.antara@gmail.com¹, mahendra.darmawiguna@undiksha.ac.id ${ }^{2}$,ardwi.pradnyana@undiksha.ac.id ${ }^{3}$
}

\begin{abstract}
Abstrak- Pelayanan publik adalah kegiatan atau rangkaian kegiatan dalam rangka pemenuhan kebutuhan pelayanan sesuai dengan peraturan perundangundangan bagi setiap warga negara dan penduduk atas barang, jasa dan/atau pelayanan administratif yang diselenggarakan oleh penyelenggara pelayanan publik. Namun masyarakat sering kesulitan dalam mencari dan mengetahui informasi layanan umum yang ada di Kabupaten Buleleng, sehingga perlu adanya sebuah sistem informasi yang dapat mempermudah masyarakat dalam menemukan dan mengetahui lokasi serta informasi layanan umum khususnya di Kabupaten Buleleng. Hal itu didukung dan diperkuat dari survey terhadap 35 responden yang menunjukkan bahwa $100 \%$ responden mendukung adanya sebuah sistem informasi layanan umum di Kabupaten Buleleng. Penelitian ini menggunakan metode Research and develpoment $(\mathrm{R} \& \mathrm{D})$ dengan model yang digunakan adalah ADDIE tahapnya meliputi, Analysis, Design, Development, Implementation, and Evaluations. Hasil dari penelitian ini adalah aplikasi yang diimplementasikan dengan framework flutter. Hasil yang diperoleh dari pengujian black box dan pengujian whitebox, yaitu semua proses dapat bekerja dengan baik dan sesuai dengan fungsinya. Adapun pengujian UEQ terhadap aplikasi yang dikembangkan masuk dalam rentangan sangat baik.
\end{abstract}

Kata kunci: Layanan Umum, Sistem Informasi Geografis, Mobile.

Abstract-Public service is an activity or series of activities in order to fulfill service needs in accordance with the laws and regulations for every citizen and resident for administrative goods, services and/or services organized by public service providers. But people often find difficulties in finding and knowing public service information in Buleleng
Regency, so there needs to be an information system that can make it easier for people to find and know the location and information of public services, especially in Buleleng Regency. This was supported and strengthened from a survey of 35 respondents which showed that $100 \%$ of respondents supported the existence of a public service information system in Buleleng Regency. This study uses the Research and Develpoment (R\&D) method with the model used is the ADDIE stage includes, Analysis, Design, Development, Implementation, and Evaluations. The results of this study are applications that are implemented with flutter framework. The results obtained from black box testing and whitebox testing, namely all processes can work well and in accordance with its functions. The UEQ testing of applications developed in the range is very good.

Keywords: Public Services, Geographic Information Systems, Mobile.

\section{PENDAHULUAN}

Dalam Undang-Undang Nomor 25 tahun 2009 tentang Pelayanan Publik, ditegaskan dalam Pasal 1 butir 1 : "Pelayanan publik adalah kegiatan atau rangkaian kegiatan dalam rangka pemenuhan kebutuhan pelayanan sesuai dengan peraturan perundang-undangan bagi setiap warga negara dan penduduk atas barang, jasa dan/atau pelayanan administratif yang diselenggarakan oleh penyelenggara pelayanan publik". Keputusan Menteri Pendayagunaan Aparatur Negara Nomor. 63 Tahun 2003 mendefinisikan pelayanan publik sebagai : "Segala bentuk pelayanan yang dilaksanakan oleh Instansi Pemerintah di Pusat, di Daerah dan di lingkungan Badan Usaha Milik Negara atau Badan Usaha Miliki Daerah dalam bentuk barang dan atau jasa, baik dalam rangka upaya pemenuhan kebutuhan masyarakat maupun dalam rangka pelaksanaan ketentuan peraturan 
perundang-undangan". Berdasarkan keputusan MENPAN No.63/KEP/MENPAN/7/2003 kegiatan pelayanan umum atau publik antara lain: (a) Pelayanan administratif yaitu pelayanan yang menghasilkan berbagai bentuk dokumen resmi yang dibutuhkan oleh publik, misalnya status kewarganegaraan, sertifikat kompetensi, kepemilikan atau penguasaan terhadap suatu barang dan sebagainya. Dokumen-dokumen ini antara lain Kartu Tanda Pendudukan (KTP), akte Kelahiran, Akte Kematian, Buku Pemilik Kendaraan Bermotor (BPKB), Surat Ijin Mengemudi (SIM), Surat Tanda Kendaraan Bermotor (STNK), Ijin Mendirikan Bangunan (IMB), Paspor, Sertifikat kepemilikan atau penguasaan Tanah dan sebagainya; (b) Pelayanan barang yaitu pelayanan yang menghasilkan berbagai bentuk atau jenis barang yang digunakan oleh publik, misalnya jaringan telepon, penyediaan tenaga listrik, air bersih dan sebagainya; (c) Pelayanan jasa yaitu pelayanan yang menghasikan berbagai bentuk jasa yang dibutuhkan oleh publik, misalnya pendidikan, pemeliharaan kesehatan, penyelenggaraan transportasi, pos dan sebagainya. Keberadaan layanan umum di masyarakat sangatlah penting, namun dengan wilayah yang luas masyarakat sulit untuk menemukan atau mencari suatu lokasi layanan umum yang akan di cari. Sehingga masyarakat hanya mengetahui lokasi-lokasi layanan umum yang sering di kunjungi dan yang tempatnya strategis. Oleh karena itu masyarakat kesulitan dalam mencari dan mengetahui informasi layanan umum yang ada di Kabupaten Buleleng, sehingga perlu adanya sebuah sistem informasi yang dapat mempermudah masyarakat dalam menemukan dan mengetahui lokasi serta informasi layanan umum khususnya di Kabupaten Buleleng.

Berdasarkan angket yang telah diserbar pada tanggal 27 Mei 2017 mengunakan fitur google form dengan 35 responden menunjukkan bahwa $100 \%$ responden mendukung adanya sebuah sistem informasi layanan umum di Kabupaten Buleleng. Karena keberadaan layanan umum sangatlah penting bagi masyarakat dan didukung oleh sebagian besar masyarakat yang telah menggunakan smartphone dimana media peta (maps) pada smartphone dapat mempermudah untuk mencari suatu lokasi layanan umum. $81 \%$ responden menyatakan bahwa tidak mengetahui secara keseluruhan lokasi layanan umum serta kesulitan dalam mencari suatu lokasi layanan umum di Kabupaten Buleleng.

Crowdsourcing merupakan gabungan dari kata "crowd" dan "outsourcing". Menurut kamus Merriam-Webster, crowdsourcing adalah proses mendapatkan sumber informasi untuk layanan yang dibutuhkan, ide, atau konten dengan meminta kontribusi dari sekelompok besar orang. Tujuan dari penggunaan metode crowdsourcing pada penelitian ini sebagai metode pengumpulan data, karena data yang bersumber dari admin terbatas dan memerlukan waktu yang cukup lama untuk mengumpulkan data. Sedangkan dengan metode crowdsourcing dapat mempercepat proses pengumpulan data serta data tersebut bersumber dari masyarakat. Untuk melakukan crowdsourcing dengan baik, terdapat langkah-langkah yang perlu dilakukan[1].

Berdasarkan uraian di atas, peneliti ingin melakukan penelitian yang berjudul Pengembangan Aplikasi Mobile Crowdsourcing Informasi Layanan Umum (Studi Kasus di Kabupaten Buleleng).

\section{KAJIAN TEORI}

\section{A. Crowdsourcing}

Crowdsourcing merupakan gabungan dari kata "crowd" dan "outsourcing". Menurut kamus Merriam-Webster, crowdsourcing adalah proses mendapatkan sumber informasi untuk layanan yang dibutuhkan, ide, atau konten dengan meminta kontribusi dari sekelompok besar orang. Tujuan dari penggunaan metode crowdsourcing pada penelitian ini sebagai metode pengumpulan data, karena data yang bersumber dari admin terbatas dan memerlukan waktu yang cukup lama untuk mengumpulkan data. Sedangkan dengan metode crowdsourcing dapat mempercepat proses pengumpulan data serta data tersebut bersumber dari masyarakat. Untuk melakukan crowdsourcing dengan baik, terdapat langkah-langkah yang perlu dilakukan[1]. Langkahlangkah tersebut dapat dilihat pada gambar berikut.

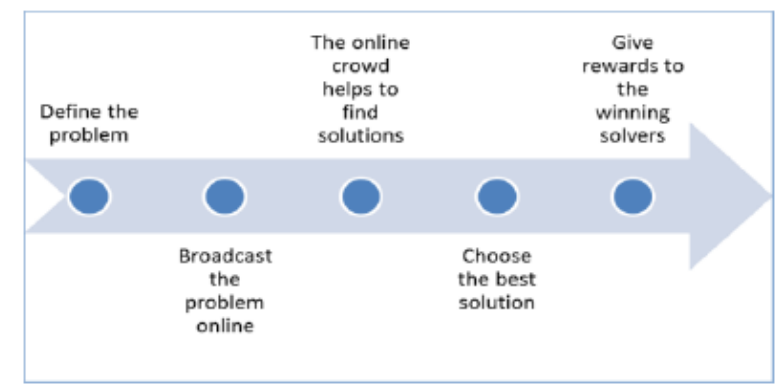

Gambar 1 Langkah-langkah crowdsourcing

\section{B. Layanan Umum}

Dalam Undang-Undang Nomor 25 tahun 2009 tentang Pelayanan Publik, ditegaskan dalam Pasal 1 butir 1 : "Pelayanan publik adalah kegiatan atau rangkaian kegiatan dalam rangka pemenuhan kebutuhan pelayanan sesuai dengan peraturan perundang-undangan bagi setiap warga negara dan penduduk atas barang, jasa dan/atau pelayanan administratif yang dielenggarakan oleh penyelenggara pelayanan publik". Keputusan Menteri Pendayagunaan Aparatur Negara Nomor. 63 Tahun 2003 mendefenisikan pelayanan publik sebagai: "Segala bentuk pelayanan yang dilaksanakan oleh Instansi Pemerintah di Pusat, di Daerah dan di lingkungan Badan Usaha Milik Negara atau Badan Usaha Miliki Daerah dalam bentukbarang dan atau jasa, baik dalam rangka upaya pemenuhan kebutuhan masyarakat 
maupun dalam rangka pelaksanaan ketentuan peraturan perundang-undangan". Mengikuti defenisi tersebut di atas, pelayanan publik atau pelayanan umum dapat didefinisikan sebagai segala bentuk kegiatan pelayanan umum yang dilaksanakan oleh instansi pemerintah di pusat, di daerah, dan lingkungan Badan Usaha Milik Negara (BUMN) maupun Badan Usaha Milik Daerah (BUMD) dalam bentuk barang dan jasa baik dalam rangka upaya pemenuhan kebutuhan masyarakat maupun dalam rangka pelaksanaan ketentuan perundang-undangan. Hakekat Pelayanan Publik antara lain :

a. Meningkatkan mutu dan produktivitas pelaksanaan tugas dan fungsi pemerintah di bidang pelayanan publik.

b. Mendorong upaya mengefektifkan sistem dan tata laksana pelayanan, sehingga pelayanan publik dapat diselenggarakan lebih berdaya guna dan berhasil guna.

c. Mendorong tumbuhnya kreativitas, prakasa, dan peran serta masyarakat dalam derap langkah pembangunan serta dalam upaya meningkatkan kesejahteraan masyarakat luas.

Pada dasarnya pembangunan nasional suatu bangsa dilaksanakan oleh masyarakat bersama pemerintah, masyarakat adalah pelaku utama pembangunan, sedangkan pemerintah berkewajiban untuk mengarahkan, membina serta menciptakan suasana kondusif yang menunjang kegiatan rakyatnya. Kegiatan masyarakat dan pemerintah tersebut harus saling mengisi, saling menunjang, dan saling melengkapi dalam suatu kesatuan langkah menuju tercapainya suatu tujuan pembangunan nasional suatu bangsa. Pemberian pelayanan umum oleh aparatur pemerintah kepada masyarakat adalah merupakan perwujudan dari fungsi aparat negara, agar terciptanya suatu keseragaman pola dan langkah pelayanan umum oleh aparatur pemerintah perlu adanya suatu landasan yang bersifat umum dalam bentuk pedoman tata laksana pelayanan umum. Pedoman ini merupakan penjabaran dari hal-hal yang perlu mendapatkan perhatian dalam prosedur operasionalisasi pelayanan umum yang diberikan oleh instansi pemerintah baik di pusat maupun di daerah secara terbuka dan transparan.

\section{Mobile Device}

Mobile Device yaitu alat elektronik yang ukurannya cukup kecil untuk bisa dipegang di tangan[2]. Mobile device memiliki bermacam-macam jenis salah satunya adalah smartphone. Smartphone merupakan mobile device yang memiliki sistem operasi untuk masyarakat luas, dimana pengguna dapat dengan bebas menambahkan aplikasi, menambah fungsi-fungsi atau mengubah sesuai keinginan pengguna. Dengan kata lain, telepon cerdas merupakan komputer mini yang mempunyai kapabilitas sebuah telepon[3].

\section{Geographic Information System}

Pengertian sistem menurut Schronderberg (1971) dalam Fatta (2007) sistem adalah komponen-komponen yang saling berhubungan satu sama lainnya. Sistem merupakan suatu keseluruhan tanpa memisahkan komponen pembentuknya, bersama-sama dalam mencapai tujuan, memiliki input dan output yang dibutuhkan oleh sistem lainnya. Pada suatu sistem terdapat proses yang mengubah input menjadi output, sistem juga memiliki subsistem yang lebih kecil dan memiliki tujuan yang sama meskipun mulainya berbeda[4].

Geographic Information System (Sistem Informasi Geografis) mulai dikenal pada awal 1980-an. Sejalan dengan berkembangnya perangkat komputer, baik perangkat lunak maupun perangkat keras, Sistem Informasi Geografis berkembang sangat pesat pada era 1990-an. Secara harafiah Sistem Informasi Geografis dapat diartikan sebagai: "Suatu komponen yang terdiri dari perangkat keras, perangkat lunak, data geografis dan sumber daya manusia yang bekerja bersama secara efektif untuk menangkap, menyimpan, memperbaiki, memperbaharui, mengelola, memanipulasi, mengintegrasikan, menganalisa dan menampilkan data dalam suatu informasi berbasis geografis".

Sistem Informasi Geografis mempunyai kemampuan untuk menghubungkan berbagai data pada suatu titik tertentu dibumi, menggabungkannya, menganalisa dan akhirnya memetakan hasilnya. Aplikasi Sistem Informasi Geografis menjawab beberapa pertanyaan seperti lokasi, kondisi, trend, pola dan pemodelan. Kemampuan inilah yang membedakan Sistem Informasi Geografis dari sistem informasi lainnya. Dilihat dari definisnya, Sistem Informasi Geografis adalah suatu sistem yang terdiri dari berbagai komponen yang tidak dapat berdiri sendiri. Sebagaimana sistem komputer pada umumnya, Sistem Informasi Geografis hanyalah sebuah 'alat' yang mempunyai kemampuan khusus. Kemampuan sumber daya manusia untuk memformulasikan persoalan dan menganalisa hasil akhir sangat berperan dalam keberhasilan Sistem Informasi Geografis. Sistem Informasi Geografis ini sangat berkaitan dengan penginderaan jauh, data spasial dan proyeksi. Melalui proyeksi peta diharapkan penggambaran permukaan bumi ke dalam peta tidak terlalu menyimpang dari aslinya, atau dapat mendekati bentuk yang sebenarnya. Sistem Informasi Geografi merupakan langkah selanjutnya setelah proses penginderaan jauh dalam rangkaian pengolahan informasi geografi. Citra yang diperoleh melalui penginderaan jauh merupakan data dasar atau input yang selanjutnya diolah dan disajikan oleh sistem informasi geografi. Dalam SIG juga terdapat beberapa jenis data yaitu data Raster dan data Vektor. Model data raster ini menampilkan, menempatkan, dan menyimpan data spasial dengan menggunakan struktur matriks atau piksel-piksel yang membentuk grid sedangkan model data vektor menampilkan, menempatkan, dan menyimpan data spasial 
dengan menggunakan titik, garis garis atau kurva atau poligon beserta atribut-atributnya[5].

\section{E. Google Map API}

Google Maps Service adalah sebuah jasa peta global virtual gratis dan online yang disediakan oleh perusahaan Google. Google Maps yang dapat ditemukan di alamat http://maps.google.com. Google Maps menawarkan peta yang dapat diseret dan gambar satelit untuk seluruh dunia. Google Maps juga menawarkan pencarian suatu tempat dan rute perjalanan[6].

API adalah kependekan dari Application programming interface. Dengan bahasa yang lebih sederhana, API adalah fungsi fungsi pemrograman yang disediakan oleh aplikasi atau layanan agar layananan tersebut bisa di integrasikan dengan aplikasi yang kita buat. Jadi Google Maps API adalah fungsi-fungsi pemrograman yang disediakan oleh Google Maps agar Google Maps bisa di integrasikan kedalam web atau aplikasi yang sedang buat[7]. Google Maps API menyediakan beberapa fitur untuk memanipulasi peta, dan menambah konten melalui berbagai jenis services yang dimiliki, serta mengijinkan kepada pengguna untuk membangun aplikasi enterprise di dalam websitenya. Pengguna dapat memanfaatkan layanan-layanan yang ditawarkan oleh Google Maps setelah melakukan registrasi dan mendapatkan Google Maps API Key[6]. Google Maps $A P I$ bisa dipakai secara gratis, namun request peta maksimal yang diperbolehkan hanya 2.500 request/perhari. Jika lebih dari itu, kita harus membeli lisensi Google Maps API for Bisnis.[7].

Aplikasi yang dapat dibuat dengan memanfaatkan Google Maps API adalah semua aplikasi yang membutuhkan layanan peta. Google Maps API dapat dimanfaatkan untuk merealisasikannya membuat aplikasi yang berhubungan dengan lokasi dan tempat[7]. Fungsi yang disediakan oleh Google Maps API yaitu:

1. Google maps Javascript API v3

Google Maps javascript API v3 adalah API versi yang ke 3 dimanaAPI tersedia dalam bahasa javascript.

2. Google Maps API Webservice

Google Maps API Webservice merupakan layanan Google maps API untuk fungsi lanjutan seperti direction, Geocoding, Distance Matrix API dan elevation API.

3. Google Place API

Google Place API dipergunakan untuk membuat aplikasi Location based service.

4. Google Earth API

5. Google Maps Image API

Pilihannya peta pada Google Maps API ada 4 jenis yaitu Roadmap, Satellite, Terrain, dan Hybrid[8]. Penjelasan lebih lanjutnya yaitu:
1. ROADMAP, ini yang saya pilih, untuk menampilkan peta biasa 2 dimensi

2. SATELLITE, untuk menampilkan foto satelit

3. TERRAIN, untuk menunjukkan relief fisik permukaan bumi dan menunjukkan seberapa tingginyasuatu lokasi, contohnya akan menunjukkan gunung dan sungai

4. $H Y B R I D$, akan menunjukkan foto satelit yang diatasnya tergambar pula apa yang tampil pada ROADMAP (jalan dan nama kota).

\section{METODE PENELITIAN}

Jenis penelitian yang digunakan adalah penelitian pengembangan. Dalam penelitian pengembangan ini, produk pengembangan aplikasi informasi layanan umum menggunakan model ADDIE (Analysis, Design, Development, Implementation, Evaluation). Model ADDIE terdiri dari 5 tahap pengembangan yaitu :

1. Analyze (Analisis)

2. Design (Perancangan)

3. Development (Pengembangan)

4. Implement (Implementasi)

5. Evaluate (Evaluasi)

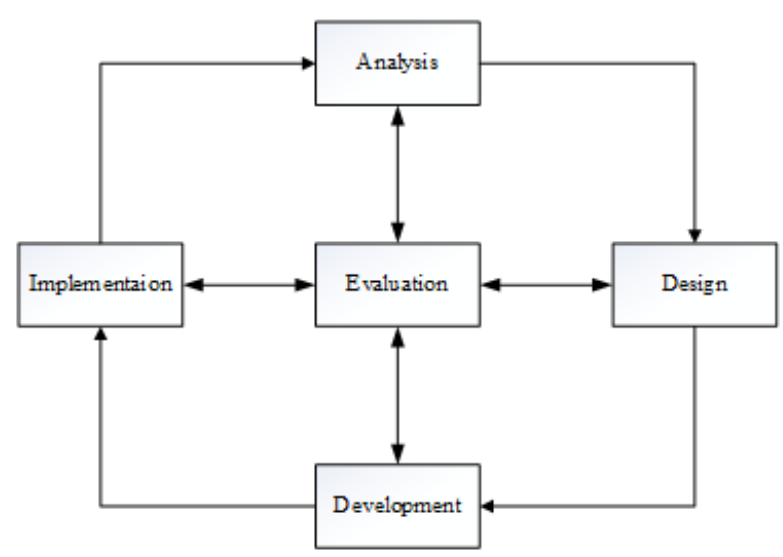

Gambar 2 Metodologi Pengembangan

\section{ANALYZE (ANALISIS)}

Pada tahap analisis, dilakukan pendefinisian permasalahan instruksional, tujuan instruksioanal, dan sasaran. Tahap ini juga merupakan tahap untuk mengumpulkan kebutuhan secara lengkap kemudian menganalisis dan mendefinisikan kebutuhan yang harus dipenuhi oleh program yang akan dibangun. Peneliti mencari informasi terkait dengan sistem yang akan dibangun, baik melalui kuisioner dan penetian terkait yang sudah pernah di kembangkan. Setelah semua data terkumpul, kemudian dilakukan analisis kebutuhan sistem dan menentukan batasan 
masalah dari sistem yang akan dibuat, sehingga pengembangan sistem bisa lebih jelas.

\section{DESIGN (PERANCANGAN)}

Pada tahap desain, dilakukan secara sistematis dan spesifik. Tahap ini dilakukan setelah tahap analisis dan pendefinisian kebutuhan sistem. Pada tahap ini merupakan tahapan perancangan sistem agar sistem yang akan dikembangkan sesuai dengan kebutuhan prangkat lunak yang telah dilakukan pada tahap analisis. Sistem ini dibangun dengan gambaran dan desain yang jelas agar pengembang sistem, bisa lebih terstruktur dalam mengembangkannya sehingga dapat mentranslasi kebutuhan perangkat lunak dari tahap analisis menuju ke representatif desain agar dapat diimplementasikan menjadi program pada tahap selanjutnya.

a. Use Case Diagram

Use case diagram merupakan pemodelan untuk kelakuan (behavior) sistem informasi yang akan dibuat. Use case digunakan untuk mengetahui fungsi apa saja yang ada di dalam sistem informasi dan siapa saja yang berhak menggunakan fungsi-fungsi tersebut. Use case menggambarkan kebutuhan sistem dari sudut pandang pengguna (user), memfokuskan pada proses komputerisasi (automated process).

b. Activity Diagram

Activity Diagram menggambarkan workflow (aliran kerja) atau aktivitas dari sebuah sistem atau proses bisnis. Activity diagram menggambarkan aktivitas dalam sistem yang sedang berjalan, bagaimana masingmasing alur berawal, decision yang mungkin terjadi, dan bagaimana aktivitas itu berakhir.

c. Perancangan Antarmuka Sistem

Perancangan antarmuka perangkat lunak merupakan gambaran dari rancangan antarmuka pada sistem yang akan diimplementasikan.. Rancangan antarmuka yang dibuat bersifat minimalis dan dibuat sesimpel mungkin agar pengguna yang menggunakan sistem merasa nyaman dan mudah menggunakannya.

\section{DEVELOPMENT (PENGEMBANGAN)}

Tahap development adalah tahapan pengembangan terhadap rancangan yang telah dibuat yang diimplementasikan dalam bahasa pemmrograman untuk membangun sistem ini secara nyata. Dalam proses pengembangan, tentunya peneliti membutuhkan beberapa perangkat yang akan digunakan dalam mengimplementasikannya. Adapun kebutuhan perangkat tersebut dapat dikategorikan menjadi 2 yaitu perangkat keras dan perangkat lunak.

\section{IMPLEMENT (IMPLEMENTASI)}

Pada tahap ini, sistem yang sudah dikembangkan pada tahap development akan diimplementasikan ke dalam web server dan application server. Selanjutnya, sistem dan aplikasi ini akan diujicoba kepada beberapa masyarakat. Metode uji coba yang akan dilakukan yaitu dengan metode User Experience Questionaire (UEQ), black box testing dan white box testing. Black box testing berkonsentrasi dari sisi kesesuaian perangkat lunak yang dibangun dengan kebutuhan pengguna yang telah didefinisikan pada saat awal perancangan dan white box testing adalah pengujian yang didasarkan pada pengecekan terhadap detail perancangan, menggunakan struktur kontrol dari desain program secara prosedural untuk membagi pengujian ke dalam beberapa kasus pengujian.

\section{EVALUATE (EVALUASI)}

Tahap evaluate merupakan tahap penyimpulan dari pengembangan dan pengujian sistem. Jika terjadi ketidak sempurnaan atau sistem menampilkan hasil yang berbeda dari yang diharapkan, maka diperlukan suatu tindakan revisi atau pengubahan yang nantinya akan diimplementasikan ke tahap selanjutnya.

\section{HASIL DAN PEMBAHASAN}

\section{ANALYZE (ANALISIS)}

Analisis kebutuhan sistem dilakukan dengan menggunakan kuisioner yang diberikan kepada masyarakat. Pada tahap ini dilakukan untuk mengumpulkan informasi, apakah diperlukan adanya sebuah sistem informasi layanan umum di Kabupaten Buleleng. Setelah semua data terkumpul, kemudian dilakukan analisis kebutuhan sistem, sehingga pengembangan sistem bisa lebih jelas dan bisa diselesaikan sesuai dengan waktu yang tersedia.

a. Analisis Kebutuhan Sistem

Berdasarkan analisa terhadap pengembangan aplikasi informasi layanan umum di Kabupaten Buleleng, ada beberapa proses yang akan diimplementasikan pada aplikasi ini, yaitu:

1. Kebutuhan fungsional

Kebutuhan Fungsional adalah kebutuhan yang berisi proses-proses apa saja atau layanan apa saja yang nantinya harus disediakan oleh sistem.

a. Kebutuhan fungsional sistem administrator

1) Sistem dapat mengelola data kecamatan.

2) Sistem dapat mengelola data desa.

3) Sistem dapat mengelola data layanan umum.

4) Sistem dapat mengelola data pengguna aplikasi.

5) Sistem dapat mengelola laporan atau ulasan data lokasi yang di laporkan.

b. Kebutuhan fungsional sistem pengguna 
1) Sistem dapat menambahkan data layanan umum dan melihat detail informasi layanan umum.

2) Sistem dapat melakukan pencarian terhadap suatu lokasi layanan umum.

3) Sistem dapat memberikan ulasan dan rating terhadap sebuah informasi layanan umum.

4) Sistem dapat mengelola data akun.

2. Kebutuhan Non-Fungsional

Kebutuhan Non-Fungsional adalah kebutuhan yang menitikberatkan pada properti prilaku yang dimiliki oleh sistem. Adapun kebutuhan nonfungsional sistem informasi layanan umum ini, yaitu:

a. Portability, sistem informasi layanan umum ini dapat digunakan pada beberapa sistem operasi mobile (multiplatform).

b. Security, sistem informasi layanan umum ini dilengkapi dengan proses login untuk masuk keberanda aplikasi.

c. Usability, sistem informasi layanan umum ini memiliki rancangan antarmuka yang user friendly dan mudah dioperasikan.

3. Kebutuhan Perangkat Lunak

Berdasarkan analisa yang telah dilakukan, kebutuhan perangkat lunak yang dibutuhkan untuk mengembangkan sistem adalah sebagai berikut:

a. Sublime Text 3 sebagai text editor untuk development.

b. Flutter untuk membuat aplikasi mobile pengguna

c. MySQL sebagai penyedia database.

d. Adobe Photoshop untuk membuat desain grafis.

e. XAMPP untuk server local database dan web admin

f. Mockplus untuk membuat rancangan antarmuka

4. Kebutuhan Perangkat Keras

a. Laptop Asus N46JV

b. RAM 8 GB dan Hardisk 1 TB

c. Processor Intel Core i7 4700HQ

2. Model Fungsional

Model Fungsional ini dilakukan dengan menggunakan UML (Unified Modelling Language). Adapun diagram UML yang digunakan dalam penelitian ini sebagai representasi alur kerja dari aplikasi diantaranya, Use Case Diagram.

1. Use Case Diagram
Adapun Use Case Diagram yang merupakan hasil dari analisis kebutuhan sistem yaitu:

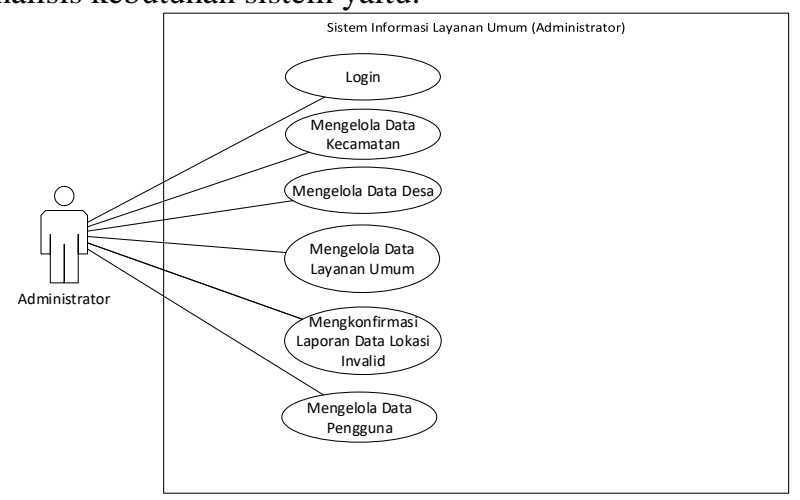

Gambar 3 Use Case Diagram Sistem (Administrator)

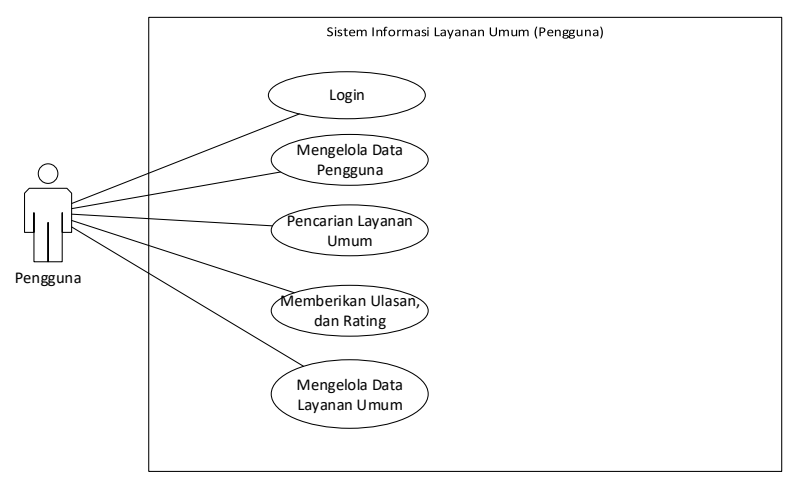

Gambar 4 Use Case Diagram Sistem (Pengguna)

Dalam pengembangan sistem ini, terdiri dari 2 user yaitu Administrator dan Pengguna.

2. DESIGN (PERANCANGAN)

a. Arsitektur Sistem

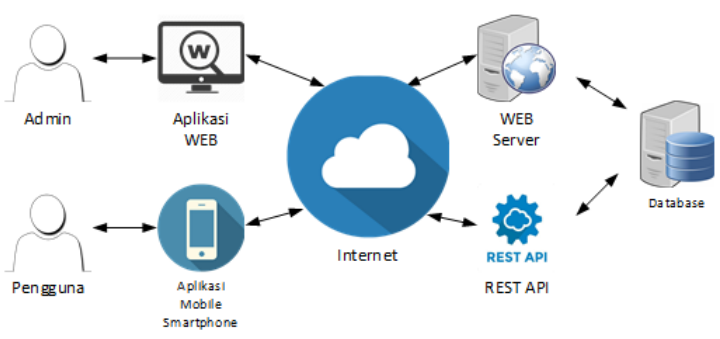

Gambar 4 Arsitektur Sistem

b. Rancangan Antarmuka

1. Rancangan Antarmuka Administrator Rancangan antarmuka administrator terdiri dari halam login, halaman beranda, halaman manajemen data, serta halaman form input 
a. Halaman Login

Pada gambar 5 adalah rancangan design antarmuka pada halaman login antarmuka admininistrator

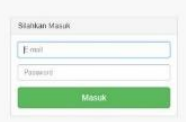

Gambar 5 Halaman Login

b. Halaman Beranda

Pada gambar 6 adalah rancangan design antarmuka pada halaman beranda antarmuka admininistrator

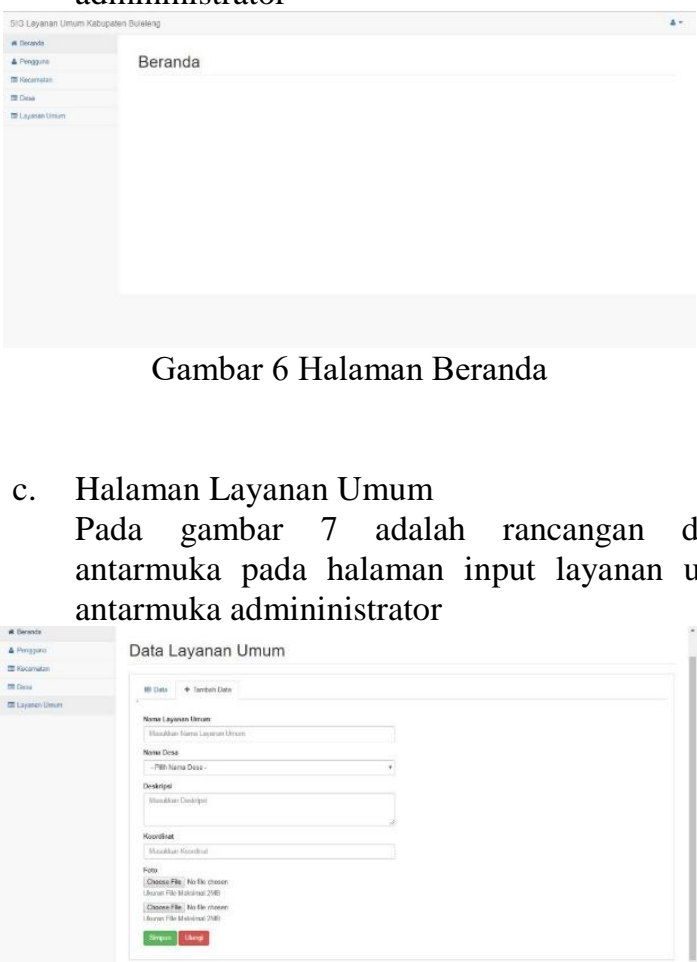

Gambar 7 Halaman Form Layanan Umum

Pada gambar 8 adalah rancangan design antarmuka pada halaman data layanan umum antarmuka admininistrator

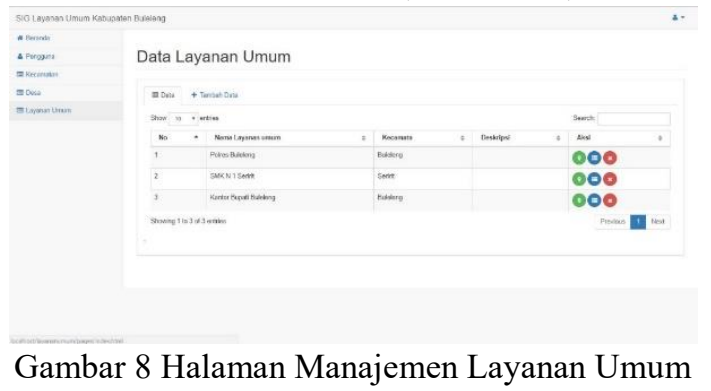

2. Rancangan Antarmuka Pengguna

Rancangan antarmuka pengguna memiliki tampilan antarmuka berbasis aplikasi mobile.

a. Halaman Login

Pada gambar 9 adalah rancangan design antarmuka pada halaman login antarmuka pengguna

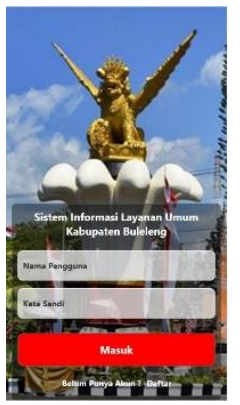

Gambar 9 Halaman Login

b. Beranda

Pada gambar 10 adalah rancangan design antarmuka pada halaman beranda antarmuka pengguna

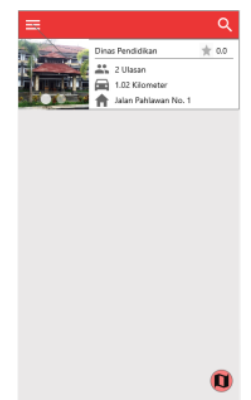

Gambar 10 Halaman Beranda 
c. Menu

Pada gambar 11 adalah rancangan design antarmuka pada halaman menu antarmuka pengguna

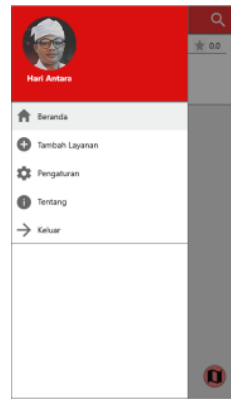

Gambar 11 Halaman Menu

d. Detail

Pada gambar 12 adalah rancangan design antarmuka pada halaman detail layanan umum antarmuka pengguna

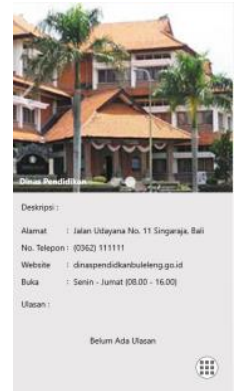

Gambar 12 Halaman Detail

\section{DEVELOPMENT (PENGEMBANGAN)}

a. Pengambangan Arsitektur Sistem

Hasil arsitektur sistem dari pengembangan aplikasi ini dapat dilihat pada Gambar 4 disana digambarkan interaksi yang terjadi antara admin, pengguna, dan sistem aplikasi yang ada. Admin mengakses dan menyimpan data ke dalam database melalui akses aplikasi web dan jaringan internet. Sedangkan pengguna mengakses aplikasi dengan menggunakan aplikasi mobile serta didukung dengan jaringan internet untuk mengakses data pada database.

b. Pengambangan Rancangan Antarmuka

Pada tahap pengembangan ini adalah membuat antarmuka aplikasi mobile dan aplikasi web sesuai dengan rancangan yang telah dibuat sebelumya ke dalam bentuk surce code atau kode program.
1. Implementasi Antarmuka Administrator Rancangan antarmuka administrator terdiri dari halam login, halaman beranda, halaman manajemen data, serta halaman form input data.

a. Halaman Login

Gambar 13 adalah hasil dari implementasi rancangan antarmuka administrator halaman login

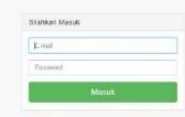

Gambar 13 Halaman Login

b. Halaman Beranda

Gambar 14 adalah hasil dari implementasi rancangan antarmuka administrator halaman beranda

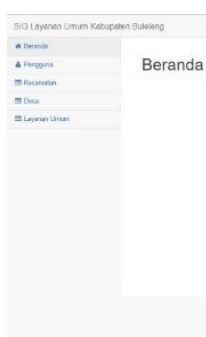

Gambar 14 Halaman Beranda

c. Halaman Layanan Umum

Gambar 15 adalah hasil dari implementasi rancangan antarmuka administrator halaman input data layanan umum

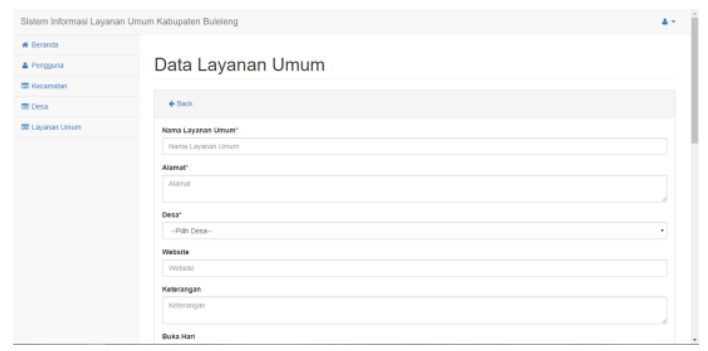


Volume 8, Nomor 2, Tahun 2019

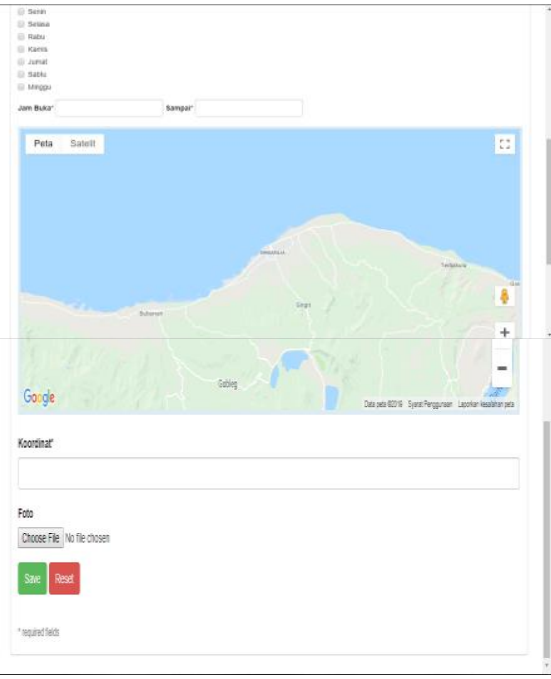

Gambar 15 Halaman Form Layanan Umum

Gambar 16 adalah hasil dari implementasi rancangan antarmuka administrator halaman tampil data layanan umum

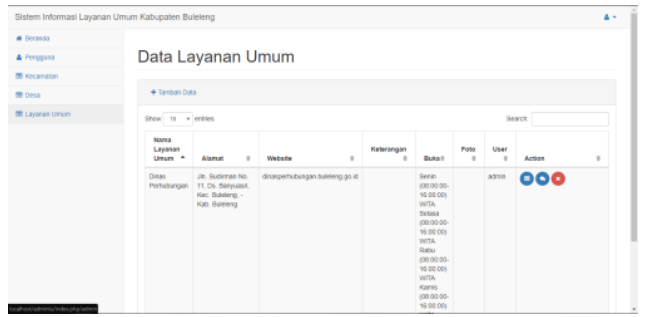

Gambar 16 Halaman Manajemen Layanan Umum

2. Implementasi Antarmuka Pengguna

Rancangan antarmuka pengguna memiliki tampilan antarmuka berbasis aplikasi mobile. Adapun halaman tampilan antarmuka untuk pengguna dirancang sesuai dengan kebutuhan fungsional.

a. Halaman Login

Gambar 17 adalah hasil dari implementasi rancangan antarmuka pengguna yaitu halaman login

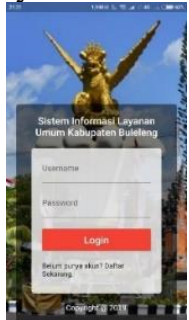

Gambar 17 Halaman Login b. Beranda

Gambar 18 adalah hasil dari implementasi rancangan antarmuka pengguna yaitu halaman tampil data layanan umum (beranda)

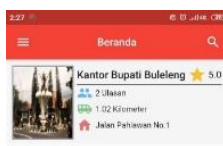

Gambar 18 Halaman Beranda

c. Menu

Gambar 19 adalah hasil dari implementasi rancangan antarmuka pengguna yaitu halaman menu aplikasi

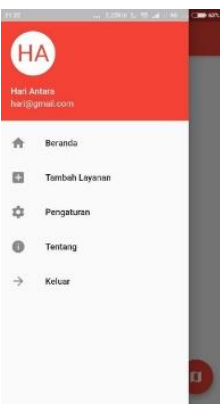

Gambar 19 Halaman Menu

d. Detail

Gambar 20 adalah hasil dari implementasi rancangan antarmuka pengguna yaitu halaman detail data layanan umum

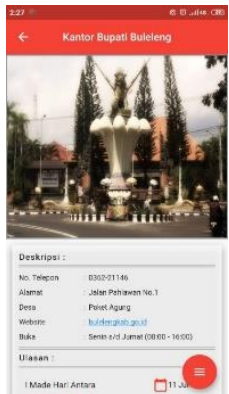

Gambar 20 Halaman Detail 


\section{IMPLEMENT (IMPLEMENTASI)}

Metode uji coba yang akan dilakukan yaitu dengan metode User Experience Questionaire (UEQ), black box testing dan white box testing. Black box testing berkonsentrasi dari sisi kesesuaian perangkat lunak yang dibangun dengan kebutuhan pengguna yang telah didefinisikan pada saat awal perancangan dan white box testing adalah pengujian yang didasarkan pada pengecekan terhadap detail perancangan, menggunakan struktur kontrol dari desain program secara prosedural untuk membagi pengujian ke dalam beberapa kasus pengujian.

Adapun pelaksanaan pengujian perangkat lunak pada Aplikasi Mobile Corwdsourcing Informasi Layanan Umum (Studi Kasus di Kabupaten Buleleng) yang dilakukan pada masing-masing pengujian, yaitu pengujian blackbox, whitebox, dan user experince questionnaire (UEQ).

\section{EVALUATE (EVALUASI)}

Berdasarkan hasil pengujian black box, white box, dan user experince questionnaire (UEQ) yang telah dilakukan. Pada tahap evaluasi merupakan tahap penyimpulan dari hasil olah data yang diperoleh dari tahap implementasi yang sudah dilakukan meliputi, pengujian black box, white box, dan user experince questionnaire (UEQ).

a. Hasil Pengujian Black Box

Berdasarkan hasil dari pengujian black box terhadap aplikasi sistem informasi geografis informasi layanan umum berbasis mobile diperoleh kesimpulan bahwa, semua kelas uji pada angket berhasil dan sesuai dengan hasil yang diharapkan.

b. Hasil Pengujian White Box

Berdasarkan hasil dari pengujian white box terhadap aplikasi Sistem Informasi Geografis diperoleh kesimpulan bahwa, semua proses source code atau kode program dapat bekerja dengan baik dan sesuai dengan fungsinya.

c. Hasil Pengujian User Experince Questionnaire (UEQ) Hasil pengujian user experince questionnaire (UEQ) untuk mengetahui penilaian pengguna tentang kelayakan dan respon pengguna terhadap aplikasi sistem informasi geografis layanan umum berbasis mobile. Hasil pengujian membuktikan dengan rata-rata pencapaian user experience berada pada tingkatan yang sangat memuaskan (excellent). Hasil dari daya tarik aplikasi (2.4), dari segi kejelasan aplikasi (2.425), dalam hal effesiensinya aplikasi (2.425), ketepatan aplikasi (2.35), stimulasi aplikasi (2.357), dan kebaruan juga dinyatakan (2.35).

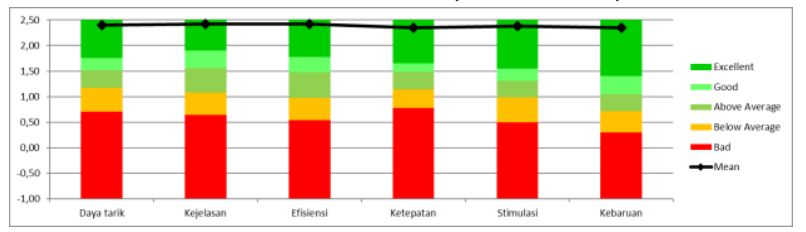

Gambar 5 Grafik Nilai Rata-Rata Kelompok

\section{SIMPULAN}

Berdasarkan analisis, perancangan, pengembangan, implementasi, dan pengujian yang telah dilakukan pada pengembangan sistem informasi geografis layanan umum berbasis mobile, diperoleh kesimpulan sebagai berikut.

1. Pengembangan dan Perancangan Sistem Informasi Layanan Umum Berbasis Mobile telah berhasil dilakukan sesuai rancangan kebutuhan sistem, Use Case Diagram, Activity Diagram, dan rancangan antarmuka dan pengembangan dilakukan dengan menggunakan framework CI (Codeigniter) untuk pengembangan rancangan administrator (Web) dan framework flutter untuk pengembangan rancangan pengguna (mobile).

2. Respon pengguna terhadap sistem yang di kembangkan sangat positif. Rata-rata pencapaian pengujian User Experince Questionnaire (UEQ) berada pada tingkatan yang sangat memuaskan (excellent). Adapun hasil dari beberapa kelompok kategori pengujian UEQ yaitu daya tarik aplikasi sangat baik (2.4, dari segi kejelasan aplikasi sangat baik (2.425), dalam hal effesiensinya aplikasi sangat baik (2.425), ketepatan aplikasi sangat baik (2.35), stimulasi aplikasi sangat baik (2.357), dan kebaruan juga dinyatakan sangat baik (2.35).

\section{REFRENSI}

[1]. Faizi, a. S., \& albarda. (2015). Perancangan Gis Monitor Kondisi Jalan Memanfaatkan Media Sosial Twitter. Jurnal edukasi dan penelitian informatika (jepin), 81-84.

[2]. Irwansyah, e., \& moniaga, j. V. (2014). Pengantar Teknologi Informasi. Yogyakarta: deepublish.

[3]. Wiryawan, w. (2012). Hubungan Pemakaian Telepon Cerdas Dengan Prestasi Siswa Sma Di Kota Medan. 1.

[4]. Fatta, h. A. (2007, september). Analisis Dan Perancangan Sistem Informasi Untuk Keunggulan Bersaing Perusahaan Dan Organisasi Modern. Retrieved july 29, 2016, from https://books.google.co.id/

[5]. Dewi, n. (2009, juni). Geografi 3 : Untuk Sma Dan Ma Kelas Xii. Retrieved 2016 30, juli, from https://id.scribd.com/doc/34305734/kelas12-geografinurmala-dewi 
Volume 8, Nomor 2, Tahun 2019

[6]. Mahdia, f., \& noviyanto, f. (2013, juni). Pemanfaatan Google Maps Api Untuk Pembangunan Sistem Informasi Manajemen Bantuan Logistik Pasca Bencana Alam Berbasis Mobile Web. Jurnal sarjana teknik informatika, 4.
[7]. Putra, c. A. (2012, september 27). Pengantar Google Maps Api. Retrieved agustus 4, 2016, from candralab: http://www.candra.web.id/pengantar-google-maps-api/

[8]. Shodiq, a. (2009). Tutorial Dasar Pemrograman Google Maps Api. Retrieved agustus 12, 2016, from http://yuliana.lecturer.pens.ac.id/google\%20maps\%20a pi/buku/tutorial\%20google\%20maps\%20api.pdf 